Niepełnosprawność. Dyskursy pedagogiki specjalnej

Joanna Iza Belzyt

Uniwersytet Gdański

\title{
Społeczne uwarunkowania sytuacji edukacyjnej osób niepełnosprawnych w krajach Afryki Południowej - wybrane aspekty
}

\section{Social factors of educational situation of people with disabilities in South African countries - the chosen aspects}

The article discusses social factors of educational situation of people with disabilities in some areas of South African countries in which citizens still remain barred access to school and other educational facilities even at basic level. Depriving citizens of access to school facilities and education remains the leading cause of increasing illiteracy rate, as well as poverty and infectious diseases. It also significantly affects social functioning of disabled people and acts as cofactor to increase in the number of persons with disabilities.

Słowa kluczowe: edukacja osób z niepełnosprawnością, sytuacja osób z niepełnosprawnością w Afryce Południowej, społeczne uwarunkowania edukacji

Keywords: education of people with disabilities, the situation of people with disabilities in South Africa, social factors of education

\section{Wprowadzenie}

Dostęp do edukacji jest powszechnie uznawany za jedno z podstawowych praw człowieka. Niemniej jednak na wielu obszarach Afryki obywatele nie mają zapewnionej możliwości pobierania nauki nawet na poziomie elementarnym, a to właśnie brak edukacji jest wskazywany jako główna przyczyna pogłębiania się ubóstwa, rozpowszechniania chorób zakaźnych czy wzrostu poziomu analfabetyzmu. Ma również kluczowe znaczenie dla funkcjonowania społecznego osób z niepełnosprawnościami oraz wzrost ich liczby ${ }^{1}$.

1 Wzrost liczby osób niepełnosprawnych w wyniku wypadków, chorób, brak opieki medycznej lub niewłaściwa jej forma (np. korzystanie z pomocy uzdrowicieli i szamanów) - wątki te zostaną szerzej omówione w dalszej części. 
Aby móc jak najpełniej zrozumieć sytuację związaną z edukacją czy realiami życia osób niepełnosprawnych konieczne jest uświadomienie sobie, iż Afryka jest drugim pod względem wielkości kontynentem, który jest najbardziej zróżnicowanym wewnętrznie.

System edukacji w krajach afrykańskich boryka się z wieloma problemami, których przyczynami jest najwyższy przyrost naturalny na świecie przy jednoczesnym najniższym wskaźniku PKB na jednego mieszkańca, co powoduje, że Afryka jest najbiedniejszym kontynentem walczącym z licznymi trudnościami (np. AIDS, głód, konflikty zbrojne). W tej sytuacji nie dziwi fakt, że tamtejszy system oświaty nie pozostaje $\mathrm{w}$ centrum zainteresowania władz, a dodatkowo sytuację bez wątpienia komplikuje fakt, że „,według danych z 2009 roku Afrykę zamieszkuje ponad miliard ludzi - ponad pięćdziesiąt narodowości, tysiące ludów i plemion posługujących się ponad tysiącem języków" (Trześniewska 2010).

Powody te generują trudność całościowego ujęcia problematyki dotyczącej edukacji (a także edukacji osób z niepełnosprawnościami), choćby z uwagi na brak danych dotyczących tych obszarów. W związku z tym w artykule ujęte zostaną jedynie wybrane aspekty.

Rozważania podejmujące wątki z zakresu edukacji osób niepełnosprawnych warto rozpocząć od nakreślenia sytuacji związanej z edukacją w wybranych krajach afrykańskich.

W Namibii „poza słońcem bardzo charakterystyczne jest również suche powietrze, które nie sprzyja uprawie większości roślin, a jednocześnie pośrednio bardzo ujemnie wpływa na rozwój gospodarczy kraju i poziom zatrudnienia jego obywateli. Jednym z dobrodziejstw Namibii są diamenty. Ponadto znaczącą gałęzią przemysłu, w której zatrudnienie znajduje spora część obywateli jest rybołówstwo. Wbrew pozorom, znalezienie pracy nie należy do łatwych zadań szczególnie dla tych, którzy nie posiadają wyższego wykształcenia (World Bank, 2009, s. 5). Oszacowano, że w 2008 roku poziom bezrobocia wyniósł 51,2\% (Central Intelligence Agency, 2011). Biorąc pod uwagę fakt, że w roku 2004 bezrobotni Namibijczycy stanowili 37\% całego społeczeństwa (World Bank, 2009, s. 12) można stwierdzić, że bezrobocie rośnie w tym kraju w bardzo szybkim tempie. Innym niepokojącym zjawiskiem jest ubóstwo, które, pomimo spadku sprzed kilkunastu lat, z $37,1 \%$ na odnotowane niedawno $28 \%$, nadal jest wysokie i dotyczy w większości rodzin mieszkających na wsiach (World Bank, 2009, s. 2). Tuż obok bezrobocia i ubóstwa, kwestią równie istotną jest występujący w szkolnictwie namibijskim niski poziom kształcenia i brak pomocy udzielanej dzieciom w odrabianiu zadań domowych przez ich rodziców, którzy sami nie ukończyli edukacji. Aby poprawić sytuację władze Namibii przeznaczają co roku $9 \%{ }^{2}$ produktu krajowego

$\overline{2}$ W Europie wskaźnik ten kształtuje się na poziomie 5\%, w Polsce w granicach 2,5\% (znp.edu.pl). 
brutto na edukację (World Bank, 2007)" (Sekułowicz, Kaniok, Sekułowicz 2013, s. 142-143). W związku z tymi nakładami finansowymi na edukację ocenia się, że w Namibii edukacja jest zorganizowana bardzo dobrze i nawet $90 \%$ dzieci chodzi do szkoły, w których nauka od kilku lat jest bezpłatna (za: okuliscidlaafryki.pl). Edukacja szkolna rozpoczyna się w wieku 7 lat i trwa siedem lat. Budynki szkolne nie mają zbyt dużej powierzchni, ale są dobrze wyposażone. W klasach poprzez to, że są skośne dachy nisko schodzące (podobnie jak w Kamerunie) do sal dociera niewiele światła słonecznego (okuliscidlaafryki.pl). Po ukończeniu pierwszego etapu edukacji dzieci mają możliwość podjęcia dalszej edukacji (etap ten jest już płatny).

Edukacja na poziomie ponadpodstawowym podzielona jest na dwa etapy ${ }^{3}$, których ukończenie (egzamin) otwiera możliwość podjęcia studiów. „Rząd Namibii poza tym, że istnieje możliwość studiowania w kraju, wysyła wielu studentów na uniwersytety w RPA lub Wielkiej Brytanii. Co ciekawe, w przeciwieństwie do Kamerunu, większość z nich wraca. Uczniowie, którzy nie zdadzą pierwszego egzaminu mogą iść na naukę zawodu wymagającego już pewnej wiedzy i umiejętności np. sekretarka, obsługa informatyczna czy techniczna" (okuliscidlaafryki.pl).

Niestety, w przeciwieństwie do Namibii, w większości krajów afrykańskich analfabetyzm jest nadal dominujący. „Według statystyk połowa mieszkańców Afryki nie umie czytać. Analfabetyzm w większym stopniu dotyczy kobiet niż mężczyzn. Jeśli dziewczyna zajdzie w ciążę, to czy będzie umiała pisać i czytać, staje się kwestią drugorzędną. Najważniejsze, aby była przyuczona do wykonywania obowiązków domowych. Inne dane mówią o $26 \%$ dzieci, które w ogóle nie rozpoczynają nauki, a wśród ponad 70\% tych, które mają do niej dostęp, tylko połowa kończy szkołę podstawową" (Trześniewska 2010). Przyczyn tego stanu rzeczy upatrywać można (por. Trześniewska 2010) w konieczności wykonywania pracy przez dzieci - wysiłek związany z pracą jest dla nich zbyt dużym obciążeniem, które powoduje, że nie mają siły, czasu ani warunków, aby się uczyć. Ocenia się, że w skali świata do pracy zarobkowej zmuszanych jest $250 \mathrm{mln}$ dzieci poniżej piętnastego roku życia. Najtrudniejsza sytuacja pod tym względem panuje właśnie w Afryce, gdzie $41 \%$ pracujących dzieci ma od 5 do 14 lat (pomocafryce.org/edukacja). W Tanzanii do części obowiązków dzieci należy praca na rzecz nauczyciela, jest to najczęściej praca na polu nauczyciela. Sytuacja ta wynika z tego, że państwa nie stać na płacenie pensji nauczycielowi, a konsekwencją jej jest to, że uczniowie wędrują ",kilometrami do szkoły nie [tylko-JIB] z tornistrem i książkami, ale z kopaczką czy maczetą do wycinania buszu" (tamże).

Problemem o równie wielkim znaczeniu dla realizacji edukacji są klasy, gdzie ilość uczniów przypadająca na jednego nauczyciela wynosi, w zależności od da-

3 Po trzech latach (po ukończeniu klasy X) odbywa się egzamin z 8 przedmiotów. Po jego zdaniu można kontynuować naukę na kolejnym etapie (dwa lata) i zdawać egzamin końcowy. 
nych od 55 do 110 osób. Brakuje też podstawowych przyborów szkolnych i podręczników (Trześniewska 2010), co potwierdzają również dane organizacji Pomoc Afryce podające, że 70\% klas nie ma podstawowego wyposażenia (ławek, biurek, krzeseł, szafek na książki, tablic) (za: pomocafryce.org/edukacja).

$Z$ dostępnych danych dotyczących edukacji (tamże) wynika, że dzieci w Afryce nie chodzą do szkoły również ze względu na:

- czynniki ekonomiczne (rodziców nie stać nawet na niskie czesne),

- trudność z dostępem do szkoły (liczba szkół jest zbyt mała, odległość do nich wynosić może nawet ponad $15 \mathrm{~km}$ ),

- konflikty wojenne,

- kryzysy ekonomiczne państwa,

- problemy zdrowotne dzieci i nauczycieli (choroba czy śmierć, np. w wyniku AIDS).

Tymczasem badania ${ }^{4}$ w sposób jednoznaczny wskazują, że wykształcenie matki (już na poziomie podstawowym) zwiększa nawet o $50 \%$ szanse dziecka na przeżycie - z poziomu 146 na 1000 żywych urodzeń w przypadku, w sytuacji gdy matka nie posiada żadnego wykształcenia do 91 na 1000 żywych urodzeń, gdy matka posiada przynajmniej wykształcenie podstawowe. Badania wskazują również jak ważna dla życia dziecka jest świadomość jego opiekunów (najczęściej jest to matka) - np. w sytuacji trudności z oddychaniem u dziecka gdy niezbędne jest natychmiastowe poszukanie pomocy medycznej w krajach Afryki poziom tej świadomości jest niepokojący: Burundi - 54\%, Niger - 20\%, Sudan - 35\%, Zambia - 8\% (dzieciafryki.com) Powyższe dane jasno wskazują, że wiedza i jej zdobywanie zwiększa świadomość, co przekłada się na szanse przeżycia dziecka i jakość jego życia.

\section{Sytuacja osób z niepełnosprawnościami w Afryce} (na podstawie sytuacji w Namibii)

Afryka, jak już zostało wspomniane, to kontynent wielu różnych krajów, narodów i kultur. Mówienie o Afryce jako o czymś jednorodnym i traktowanie jej jako całości jest błędne, chociaż wiele elementów funkcjonowania społecznego istnieje na podobnych zasadach.

Z uwagi na różnorodność i brak rozwiązań wspólnych dotyczących sytuacji i funkcjonowania osób z niepełnosprawnościami w Afryce, pisząc o tej tematyce odwoływać się będę do przykładów z Namibii. Podyktowane jest to informacjami dostępnymi w literaturze przedmiotu i portalach poświęconych sytuacji w Afry-

$\overline{4}$ Badania przytoczone przez portal DzieciAfryki.com, www.pomocafryce.org. 
ce, które wskazują, że sytuacja w Namibii „na pewno niewiele się (...) różni od sytuacji w innych rejonach czarnego lądu" (dzieciafryki.org).

Jednakże podkreślić należy, że Namibia jest jednym z niewielu krajów Afryki Południowej, który posiada ustawę o ubezpieczeniach społecznych, dzięki niej osoby niepełnosprawne, weterani, ubodzy, ludzie starsi czy sieroty mogą liczyć na pomoc państwa. Namibia prowadzi również politykę integracji osób niepełnosprawnych ze społeczeństwem, ale większość założeń jest nadal w sferze idei, a realia odbiegają od nich znacznie (por. Sekułowicz, Kaniok, Sekułowicz 2013).

W listopadzie 2006 roku media podały, że powstał projekt nowego prawa, na podstawie którego „niepełnosprawni w Botswanie będą jeszcze lepiej chronieni przez prawo. Podjazdy, bezpłatny transport i szereg innych ułatwień przewiduje projekt, nad którym pracuje rząd w Gaborone. Szacuje się, że w Botswanie żyje ponad 58 tys. niepełnosprawnych. Każdego miesiąca rząd wypłaca im zasiłek wysokości 10 USD i wydaje zapasy żywności na cały miesiąc o wartości 27 USD. Proponowane zmiany mają doprowadzić do poprawy losu niepełnosprawnych. Poprzez obowiązek wprowadzenia specjalnych podjazdów w budynkach użyteczności publicznej, jak i w transporcie publicznym, który powinien być bezpłatny dla niepełnosprawnych pasażerów, będzie można egzekwować znoszenie dzielących ich od normalnego życia barier. Projekt nowego prawa będzie poddany szerszej debacie $w$ nadchodzącym roku, ale minister zdrowia Lesego Motsumi już dzisiaj zapewnia - „stworzymy taki system prawny, w którym znikną bariery" (afryka.org).

Chcąc nakreślić sytuację osób niepełnosprawnych w Afryce warto przytoczyć kilka danych. Ocenia się, że 60-80 mln Afrykańczyków to osoby niepełnosprawne, co daje około $10 \%$ całej populacji kontynentu ${ }^{5}$, ale $\mathrm{w}$ rejonach najbiedniejszych współczynnik ten sięga $20 \%$ i nieustannie rośnie. Niepełnosprawność w Afryce jest powodowana najczęściej przez: niedożywienie ${ }^{6} \mathrm{i}$ choroby, przemoc, wady rozwojowe, katastrofy naturalne, wypadki oraz konflikty zbrojne. Część

5 Wskaźnik ten jest podobny do wskaźnika na terenie krajów Europy, w tym również Polski (12,5\%; dane GUS z 2012)

6 Istnieje zależność pomiędzy niedożywieniem a niepełnosprawnością. Organizm, aby mógł funkcjonować prawidłowo, potrzebuje składników odżywczych dostarczanych wraz z pożywieniem. Niedożywienie powoduje zatem wiele problemów zdrowotnych, nieraz bardzo poważnych:

- u dzieci brak odpowiedniej ilości witaminy A może powodować ślepotę, brak B1 - polineuropatię, brak B3 - zaburzenia psychiczne, brak B6 - padaczkę;

- u kobiet ciężarnych odpowiedni poziom kwasu foliowego zapobiega schorzeniom neurologicznym dziecka, a witaminy D13 i wapnia - przedwczesnym porodom, które niosą ryzyko wielu bardzo poważnych uszkodzeń płodu, łącznie z mózgowym porażeniem dziecięcym.

Choć wydawać by się mogło, że żywienie i niepełnosprawność nie ma ścisłego związku ze sobą, to powyższe dane pokazują zupełnie coś innego. W Afryce wiele rodzin żyje za mniej niż 1 \$ dziennie. Niewiele dzieci wie co to jest śniadanie, bo jedyny spożywany posiłek w ciągu dnia to posiłek wieczorny. Niektóre szkoły prowadzą programy dożywiania, ale dzieci niepełnosprawne mają mniejszy dostęp do tego rodzaju pomocy, bo nie chodzą do szkoły (dzieciafryki.org). 
następstw niepełnosprawności wynikających z powyższych czynników mogłaby zostać zniwelowana lub znacznie ograniczona przez działania rehabilitacyjne, ale mimo, że „Namibia to kraj ponad 2 razy większy niż Polska, a w roku 2013 było tam zarejestrowanych tylko 77 fizjoterapeutów (ponad połowa pracuje w stolicy kraju - Windhoek), [a dodatkowo-JIB] w Namibii nie ma uczelni, która kształciłaby przyszłych rehabilitantów" (dzieciafryki.org).

Na podstawie informacji, jakie docierają z krajów afrykańskich, można uznać, że w Afryce niepełnosprawność staje się właściwie gwarancją biedy i braku poszanowania praw oraz ludzkiej godności. Osoby niepełnosprawne w krajach, takich jak Namibia, nie mają dostępu do informacji, co powoduje, że decyzje dotyczące ich spraw podejmowane są przez rządy, bez konsultacji z nimi. Tylko $20 \%$ osób niepełnosprawnych otrzymuje potrzebną im pomoc, sprawia to, że żebranie na ulicach jest często jedynym sposobem na przeżycie (tamże). „Prowadzona przez władze namibijskie polityka integracji środowiska osób z niepełnosprawnością i ich rodzin z ludźmi pełnosprawnymi nie zawsze znajdowała odzwierciedlenie w rzeczywistości. Najlepszym tego przykładem jest dość powszechna, szczególnie na wsiach, praktyka polegająca na wykluczaniu dzieci z niepełnosprawnością ze szkół i społeczeństwa" (Sekułowicz, Kaniok, Sekułowicz 2013, s.143).

Trudną sytuację pogłębia fakt, że $60 \%$ społeczeństwa kraju żyje na terenach wiejskich, gdzie wierzenia ludowe są bardzo ważne dla życia ludności. W związku z tym niepełnosprawność pojmowana jest jako kara czy rzucony urok ${ }^{7}$, dlatego też rodziny wstydzą się swoich niepełnosprawnych bliskich. Rodzice niepełnosprawnych dzieci często starają się za wszelką cenę ukryć ten fakt, przy czym jednocześnie ignorują wszystkie potrzeby dziecka wynikające z jego niepełnosprawności i nie dają mu szansy na terapię i być może uzyskanie samodzielności w życiu dorosłym (tamże).

W tym kontekście niepokojące są informacje, że często spotykaną praktyką jest wykluczanie dzieci niepełnosprawnych ze szkół. Dane wskazują, że spośród

\footnotetext{
Pozycja szamana wśród afrykańskiej społeczności jest bardzo wysoka. Dla mieszkańców jest często jedynym źródłem pomocy medycznej. Szamanizm jest częścią tradycji i stosowana od wieków sztuki ziołolecznictwa czy innego rodzaju ingerencji. Być może często ważną rolę odgrywa też efekt placebo. Dodatkowo w tradycji Czarnego Lądu kult duchowy jest bardzo intensywny i głęboko zakorzeniony, przenikając do codziennego życia - przed chatami wiszą amulety, zmarlych grzebie się w pobliżu domu. Jednak ingerencja szamanów jest często zgubna dla pacjentów. Lekarze, którzy jeżdżą do Afryki z różnych fundacji, zgodnie twierdzą, że działania szamanów bardzo często zaburzają pewien rytm postępowania choroby, a często szkodzą. Ingerują oni w banalnych sprawach, co czasem kończy się tragicznie dla chorego. Sposobem na różne rany jest aplikowanie do ich wnętrza wszelkiego rodzaju ziół i mikstur. W parze z tym idzie najczęściej zakażenie. Pojawiają się ropiejące rany, które potem trudno jest wyleczyć. Brak przygotowania medycznego staje się brzemienne w skutkach - wykształcony medyk wie jak wykonać zastrzyk w zależności od miejsca infekcji. Szamani na skutek swojej niewiedzy często aplikują „leki", wykonując zastrzyk w miejscach, w których nie powinni, ryzykując uszkodzenie nerwów i trwałe kalectwo. Niestety, głębokie tradycje i szacunek do szamanów a także bieda powodują, że często zanim chory uda się do szpitala, odwiedza szamana w nadziei na wyleczenie (dzieciafryki.com).
} 
dzieci niepełnosprawnych jedynie około $5-10 \%$ chodzi do szkoły (dzieciafryki. org). Brak edukacji pozbawia je szans na rozwój, samodzielną przyszłość, skazuje na brak wykształcenia i życie w skrajnej biedzie.

Być niepełnosprawnym w Afryce to bez wątpienia ogromne wyzwanie.

\section{Osoby z niepełnosprawnością intelektualną}

Studiując opisy i raporty o stanie opieki medycznej dotyczącej zdrowia intelektualnego i psychicznego w Afryce można odnieść wrażenie, że kraje afrykańskie nie mają wypracowanych $\mathrm{w}$ zasadzie żadnych standardów postępowania z osobami z niepełnosprawnością intelektualną. Dodatkowo przytaczane opisy i historie są przerażające i jednoznacznie dowodzą, że niepełnosprawność intelektualna oraz choroby psychiczne nie są traktowane w Afryce jako stany wymagające opieki medycznej, przez co osoby te są pozbawiane wszelkich praw i dyskryminowane - często osoby z niepełnosprawnością intelektualną są prześladowane, wytykane palcami, obrzucane kamieniami (dzieciafryki.com).

Na portalu dzieciafryki.com można znaleźć przykłady opisujące sytuację osób z niepełnoprawnością intelektualną:

Ghana - badania prowadzone w 2012 r. przez Human Rights Watch, organizację pozarządową zajmującą się ochroną praw człowieka ukazują sytuację placówek medycznych zajmujących się zdrowiem psychicznym. Placówki te są przepełnione, a warunki higieniczne są dalekie od chociażby przyzwoitych. W Ghanie istnieją też tzw. ośrodki duchowego uzdrawiania - prywatne placówki, prowadzone przez (...) uzdrowicieli. Członkowie HRW zwizytowali 8 takich placówek, w których odkryli, że większość pacjentów pozostaje przykuta łańcuchami do drzew. W tym samym miejscu śpią, jedzą, załatwiają się i myją, często nawet przez klika miesięcy. Pośród pacjentów były również dzieci poniżej 10 roku życia.

Sudan Południowy - brak tu ośrodków dla ludzi z upośledzeniem umysłowym. Zalecenia rządu są takie, by osoby takie zamykać $\mathrm{w}$ więzieniach. W połowie 2012 r. zamknięto około 90 osób z problemami natury psychiatrycznej [i intelektualnej].

Uganda - kraj relatywnie bardziej rozwinięty, stosuje te same zasady w stosunku do osób (...) [niepełnosprawnych intelektualnie]" (dzieciafryki.com).

Sytuacja ta jest niezwykle trudna do zmiany z uwagi na to, że w obszarze systemu ochrony zdrowia rządy poszczególnych krajów nie są zainteresowane problematyką niepełnosprawności intelektualnej czy chorób psychicznych. Według statystyk $\mathrm{w}$ „krajach afrykańskich średnio na 100000 pacjentów przypada mniej niż jeden psychiatra, a w budżetach przeznaczanych na ochronę zdrowia przeznacza się tylko $1 \%$ na zdrowie psychiczne" (dzieciafryki.com). 


\section{Osoby z niepełnosprawnością słuchu}

W wielu krajach afrykańskich (również w Namibii) brakuje podstawowych działań i programów do wykrywania wad słuchu u dzieci. W żadnym szpitalu nie przeprowadza się badań, nie tylko po narodzinach dziecka, oceniając jego funkcje życiowe w momencie przyjścia na świat, ale również podczas kolejnych wizyt lekarskich czy w czasie obowiązkowych szczepień. Diagnozy nie prowadzi żadna szkoła czy przedszkole, placówki nie kierują swoich wychowanków na badania, co prowadzi do niewykrywania wad słuchu. Sytuację dodatkowo pogarsza brak świadomości rodziców, zwłaszcza tych zamieszkujących słabo rozwinięte ekonomicznie rejony wiejskie (dzieciafryki.org).

Według szacunków podaje się, że w Namibii żyje od 3 do 12 tysięcy dzieci niesłyszących lub słabosłyszących. W Namibii działa tylko jedna organizacja zajmująca się problematyką niepełnosprawności słuchu, której celem jest prowadzenie działań na rzecz dzieci z zaburzeniami słuchu i mowy. Stowarzyszenie na Rzecz Dzieci z Zaburzeniami Mowy i Słuchu (ang. The Association for Children with Language, Speech and Hearing Impairments of Namibia, CLASH)) jest organizacją niosącą pomoc dzieciom z niepełnosprawnością słuchu i ich rodzinom, która została założona w 1989 roku przez grupę rodziców dzieci niesłyszących. Stowarzyszenie to jest jednym z najbardziej znanych, namibijskich stowarzyszeń, którego działalność związana jest z takimi obszarami, jak: zdrowie, edukacja oraz prawa człowieka (Sekułowicz, Kaniok, Sekułowicz 2013). Organizacja realizuje swoje założenia w sposób interdyscyplinarny, starając się zapewnić swoim podopiecznym odpowiednią opiekę i umożliwiając dostęp do edukacji dostosowanej do ich potrzeb wynikających z niepełnosprawności, a także walcząc o ich prawa (dzieciafryki.com).

\section{Osoby z niepełnosprawnością wzroku}

Według danych Światowej Organizacji Zdrowia (WHO) na świecie żyje niemal $40 \mathrm{mln}$ osób niewidomych i $246 \mathrm{mln}$ osób słabowidzących (Skiba 2013). Prognozy WHO podają, iż w ciągu kolejnych 20 lat liczba osób z niepełnosprawnością wzroku może zwiększyć się dwukrotnie (WHO, 2009), a u 80\% osób, które stracą wzrok chorób prowadzących do tego stanu, można uniknąć (sytuacja ta dotyczy zwłaszcza krajów Afryki) (Skiba, 2013).

Powodami prognozowanego wzrostu liczby osób z niepełnosprawnością wzroku są m.in. starzejące się społeczeństwo (wzrok nieuchronnie pogarsza się wraz z wiekiem), wypadki, przedwczesne urodzenia, choroby (w krajach rozwi- 
jających się najczęstszą przyczyną utraty wzroku jest jaglica ${ }^{8}$ (Skiba, 2013), choroba nieobecna w Europie od kilkudziesięciu lat (Niżankowska 2002), która za sprawą migracji ludności może powrócić na stary kontynent).

Niepełnosprawność wzroku towarzyszy ludziom od początku istnienia, a to jak ją traktowano, zmieniało się na przestrzeni wieków. Podczas gdy dziś w wielu krajach istnieje szereg udogodnień dla niewidomych, w wielu częściach świata, w tym w Afryce, grupa ta jest zupełnie marginalizowana. „Niewidome dzieci często nie doświadczają należytej opieki, nie mają szans na edukację, a jako dorośli na pracę w jakimkolwiek zawodzie. W górzystej Rwandzie, w małej miejscowości Kibeho, istnieje miejsce, w którym niewidome dzieci zdobywają wiedzę i wykształcenie, tak samo jak ich widzący rówieśnicy. Uczą się wszystkiego, co będzie im niezbędne w samodzielnym życiu, co - mimo niepełnosprawności - da im szansę na osiągnięcie sukcesu" (Skiba 2010, s. 4). Ośrodek dla Dzieci Niewidomych, który powstał w Kibeho (Rwanda) w 2008 roku dzięki pomocy finansowej polskiego rządu, jest wyjątkiem na mapie pomocy osoby z niepełnosprawnością wzroku.

Osoby pracujące z osobami z niepełnosprawnościami nieustannie apelują o pomoc w zakładaniu ośrodków, wyposażenie ich w specjalistyczne pomoce i wsparcie finansowe niezbędne dla ich funkcjonowania. To często jedyna szansa dla dzieci i osób niepełnosprawnych na edukację - a co za tym idzie - na poprawę jakości życia.

Niewątpliwym wsparciem dla każdego z nauczycieli pracujących z uczniami z niepełnosprawnością (bez względu na to czy jest to niepełnosprawność sensoryczna czy intelektualna) byłaby profesjonalna superwizja. Taka forma mogłaby pomóc nauczycielom bez przygotowania $w$ zakresie pedagogiki specjalnej w kształceniu uczniów z niepełnosprawnościami. Rozwiązaniem dodatkowym mogłaby być instytucja nauczyciela wędrującego (itinerant teatcher). Idea powstała w USA jako wsparcie specjalistów dla nauczycieli bez przygotowania specjalistycznego do pracy z uczniem z potrzebami edukacyjnymi. Transfer wiedzy i umiejętności oraz wsparcie pośrednie realizowane jest $\mathrm{w}$ formie konsultacji indywidualnych ${ }^{9}$, szkoleń i warsztatów mających na celu uzyskanie przez nauczyciela samodzielności (Paplińska, Witczak-Nowotna 2014) ${ }^{10}$.

$\overline{8}$ Obecnie na jaglicę choruje $84 \mathrm{mln}$ ludzi, a $8 \mathrm{mln}$ utraciło wzrok bezpowrotnie z powodu choroby (WHO, 2009).

9 W zakres konsultacji wchodzi dobór metod, form i środków pracy, wskazówki dotyczące przygotowania pomocy tyflodydaktycznych (por. Paplińska, WItczak-Nowotna 2014).

${ }^{10}$ Fundacja Cedunis (cedunis.org.pl) oraz Stowarzyszenie De Facto (defacto.org.pl) realizują innowacyjny program wsparcia uczniów z niepełnosprawnością wzroku wykorzystując m.in. model nauczyciela wędrującego. 


\section{„Bariery przed życiem” na zakończenie}

Trudno jest mówić o barierach architektonicznych czy jakichkolwiek innych w kontekście osób niepełnosprawnych zamieszkujących kraje Afryki, ponieważ sytuacja społeczno-prawna z jaką borykają się te osoby, można określić jako jedną wielką barierę - „barierą przed życiem” (dzieciafryki.org).

Problemy, z którymi borykają się osoby z niepełnosprawnością w Afryce w porównaniu do np. krajów europejskich, nabiera zupełnie innego wymiaru. Osoby niepełnosprawne „walczą o to by być” (dzieciafryki.com).

"Często pierwszą barierą do uczestniczenia w życiu lokalnej społeczności jest dla osoby niepełnosprawnej jej własna rodzina. Niepełnosprawność odbierana jest w wielu rejonach Afryki jako kara wydana przez boga i powód do wstydu. Niepełnosprawne dzieci chowane są w chatach, ukrywane przed wzrokiem sąsiadów" (dzieciafryki.com).

Nawet jeśli niepełnosprawność zostanie przez rodzinę zaakceptowana, natychmiast pojawiają się kolejne bariery, choćby „brak zaopatrzenia ortopedycznego - wózków inwalidzkich, kul, ale nawet takich bardzo podstawowych, jak chociażby okulary" (dzieciafryki.org). Bez podstawowych pomocy rehabilitacyjnych czy ortopedycznych osoby z niepełnosprawnościami nie mogą nawet podjąć starań o bycie samodzielnymi, a poruszanie się po najbliższej okolicy staje się niewykonalne.

Przykłady barier ograniczających samodzielność i obniżających jakość życia osób niepełnosprawnych zamieszkujących Afrykę można mnożyć bez końca: bariery architektoniczno-komunikacyjne, $\mathrm{w}$ dostępie do edukacji dla osób o specjalnych potrzebach, brak dostępu do lekarzy i rehabilitacji (co w wielu przypadkach mogłaby przywrócić sprawność i umożliwić samodzielność), brak sprawnego zaplecza socjalnego dla osób niepełnosprawnych, czy brak organizacji pozarządowych działających na rzecz osób z niepełnosprawnościami i ich edukacji. Jak wskazują M. Sekułowicz, P.E. Kaniok, A. Sekułowicz (2013) „po dokonaniu (...) przeglądu wybranych, aktualnie funkcjonujących instytucji rządowych oraz pozarządowych, których działalność skierowana jest na pracę z dzieckiem z niepełnosprawnością i z jego rodziną, w obszarze tym zauważyć można zdecydowaną przewage organizacji dobroczynnych nad instytucjami państwowymi w zakresie ilości oraz jakości świadczonych usług. Powodem takiego stanu rzeczy jest w głównej mierze brak środków finansowych, dzięki którym państwo namibijskie mogłoby realizować uchwalone, bądź też ratyfikowane przez siebie akty prawne, dotyczące jego zobowiązań względem dzieci z niepełnosprawnością oraz ich rodzin. Sporym problemem dla organizacji charytatywnych, działających na rzecz tych dzieci, jest brak w pomocy społecznej wyraźnego podziału kompe- 
tencji pomiędzy państwem a trzecim sektorem. Sytuacja taka sprawia, że ciężar odpowiedzialności za świadczenie pomocy i wsparcia dzieciom oraz ich rodzinom całkowicie spada na organizacje pozarządowe" (Sekułowicz, Kaniok, Sekułowicz 2013, s. 150-151). Dodatkową barierą w działaniach, które mogłyby podejmować organizacje dobroczynne jest bardzo znaczący wpływ afrykańskich wierzeń ludowych na życie osób niepełnosprawnych i życie ich rodzin. Przykłady przytoczone $\mathrm{w}$ artykule wskazują jak stare afrykańskie wierzenia i przesądy, szczególnie intensywne na terenach wiejskich prowadzą do dyskryminacji osób z niepełnosprawnościami i wpływają negatywnie na traktowanie dzieci z niepełnosprawnością i ich rodzin (por. Sekułowicz, Kaniok, Sekułowicz 2013).

Edukacja i dostęp do niej przekłada się na wiele sfer funkcjonowania osoby niepełnosprawnej w społeczeństwie, m.in. na możliwość zatrudnienia. „Chociaż wiele afrykańskich krajów dysponuje prawnymi podstawami dotyczącymi różnych aspektów życia osób niepełnosprawnych, w rzeczywistości osoby te muszą na co dzień mierzyć się z dyskryminacją, także w kwestii zatrudnienia" (dzieciafryki.org).

Niechęć do rekrutowania osób niepełnosprawnych jest efektem wielu czynników, wśród których wymienić można:

- złe nastawienie społeczeństwa oraz brak wiedzy na temat niepełnosprawności,

- bariery związane z infrastrukturą - problemy komunikacyjne, ograniczona mobilność,

- brak odpowiednich kwalifikacji - wynikająca z tego, że większość niepełnosprawnych dzieci $w$ wieku szkolnym nie pobiera nauki (dzieciafryki.org).

Kolejnym powodem, który jest rzadko wymieniany, ale jest bardzo ważny, to poczucie wstydu osób niepełnosprawnych, które dokonują autoizolacji: wybierają pozostanie $\mathrm{w}$ domu i unikanie udziału w życiu społecznym.

Często też firmy, które wyrażają chęć zatrudnienia osób z niepełnosprawnością, nie potrafią poradzić sobie z problemem związanym z pojawieniem się osoby niepełnosprawnej $w$ firmie - „z jednej strony boją się, bo uważają, że raz zatrudniona osoba niepełnosprawna, zgodnie z prawem nie będzie mogła zostać zwolniona, $\mathrm{w}$ obawie przed oskarżeniem o dyskryminację. $Z$ drugiej strony wydaje się, że pracodawcy nierzadko wykazują się brakiem wiedzy i ignorancją w temacie niepełnosprawności" (dzieciafryki.org), nie zdając sobie sprawy z funkcjonalnych następstw niepełnosprawności swoich pracowników i stawiając im wymagania, którym z powodu niepełnosprawności nie są w stanie sprostać.

Mimo to (nieliczni) przedsiębiorcy zatrudniający osoby niepełnosprawne potwierdzają, że firmy czerpią korzyści z tej sytuacji.

Po pierwsze biznesowe - opinia społeczna docenia firmy dające szansę osobom marginalizowanym i wykluczonym, co powoduje, że poziom sympatii wzrasta, a zyski rosną. 
Po drugie ekonomiczne - zyski odnotowuje również ekonomia w skali krajowej: przywrócenie osoby niepełnosprawnej na rynek pracy oznacza zmniejszenie wydatków państwa na pomoc społeczną dla osób niezdolnych do pracy zarobkowej i samodzielnego utrzymania się.

Po trzecie psychologiczne - osoby, które pozytywnie przeszły integrację, prowadzą normalne życie społeczne, utrzymują kontakty z innymi ludźmi i zaczynają się uważać za pełnoprawnych członków społeczności lokalnej (dzieciafryki. org).

Powyższe przykłady pozytywnych aspektów zatrudniania osób z niepełnosprawnościami wskazują, że możliwa jest integracja społeczna osób niepełnosprawnych i sytuacja, gdy nadal „rządy krajów afrykańskich traktują swoich niepełnosprawnych obywateli tak samo jak te rodziny, które nie akceptują choroby bliskich - chowają ich i udają, że nie ma problemu, nie zdają sobie sprawy, że marnują potencjał, jaki drzemie w tych [osobach]" (dzieciafryki.org), powinna ulec jak najszybciej zmianie, zwłaszcza w sferze edukacji i dostępu do niej. Jak wskazują M. Sekułowicz, P.E. Kaniok, A. Sekułowicz (2013) idea kształcenia, zwłaszcza kształcenia inkuzyjnego (czy integracyjnego) jest mało efektywna w szkolnictwie powszechnym. „Mała liczba szkół oraz klas integracyjnych sprawia, że niewiele dzieci z nieprawidłowościami w rozwoju ma szansę na pełną integrację ze środowiskiem dzieci pełnosprawnych" (Sekułowicz, Kaniok, Sekułowicz 2013, s. 151).

Brak oferty edukacyjnej skazuje osoby niepełnosprawne na życie na marginesie społeczeństwa, często w skrajnym ubóstwie. Znając doświadczenia z innych krajów wiadomo, że tak nie musi być, a osoba niepełnosprawna może z powodzeniem pracować, być samodzielna i uczestniczyć w pełni w życiu społecznym. Kwestią kluczową jest dostęp do edukacji, bez której bycie osobą niepełnosprawną w Afryce staje się wyrokiem, który skazuje osoby na wegetację.

\section{Bibliografia}

Belzyt J. (2014), Uczeń z dysfunkcją wzroku w szkole ogólnodostępnej, „Niepełnosprawność. Dyskursy Pedagogiki Specjalnej", nr 14.

Central Intelligence Agency. (2011), The World Factbook, https://www.cia.gov/library/publications/the-world-factbook/geos/wa.html.

Chmielewska A. (2016), Tradycyjna medycyna ludów Afryki Południowej [w:] Środowisko przyrodnicze i społeczno-kultorowe strefy suchej i pótsuchej (wbrane przykłady z Afryki Potudniowej), red. M. Dłużniewski, I. Tsermegas, Warszawa

Dulias R. (2016), Sytuacja dzieci w Afryce Południowej [w:] Środowisko przyrodnicze i społecznokultorowe strefy suchej i pótsuchej (wbrane przykłady z Afryki Południowej), red. M. Dłużniewski, I. Tsermegas. Warszawa

Gmerek T.(2011), Edukacja i nierówności społeczne. Studium porównawcze na przykładzie Anglii, Hiszpanii i Rosji, Kraków. 
Heater D. (2004), A history of education for citizenship, London-New York.

Hejwosz-Gromkowska D. (2012), Społeczne funkcje szkolnictwa wyższego [w:] RPA i konstruowanie różnicy, "Studia Edukacyjne”, , nr 21.

Kobusińska K. (2012), Edukacja w Zambii, http://www.miedzykulturowa.org.pl/cms/edukacja-w-zambii.html [dostęp: 12.03.2016].

Niżankowska M.H. (2002), Podstawy okulistyki, Wrocław.

Olędzka D. (2015), Szkoła w Zambii, Warszawa.

Paplińska M., Witczak-Nowotna J. (2014), Nowy model wsparcia dla uczniów niewidomych w szkołach ogólnodostępnych - studium przypadku, http://abcd.edu.pl/index.php?option =com_content\&view =article\&id=375:nowy-model-wsparcia-dla-uczniow-niewidomych -w-szkoach-ogolnodostpnych-studium-przypadku\&catid=16:dla-nauczycieli\&Itemid =61) [dostęp: 3.03.2014].

Piotrowska I. (2016), Sysem edukacji oraz szkolnictwo wyższe w Republice Południowej Afryki [w:] Środowisko przyrodnicze i społeczno-kultorowe strefy suchej i pótsuchej (wbrane przykłady z Afryki Południowej), red. M. Dłużniewski, I. Tsermegas, Warszawa.

Skiba P. (red) (2013), Sytuacja dzieci niewidomych i stabo widzacych w Ghanie, Warszawa

Skiba P. (red) (2012), Granice mroku. Przewodnik po śwecie dzieci niewidomych z Rwandy, Warszawa

Sekułowicz M., Kaniok P.E., Sekułowicz A. (2013), Wybrane formy kształcenia, Rehabilitacji i wsparcia dzieci z niepetnosprawnościa i ich rodzin w republice Namibii, „Forum oświatowe”, vol. 1(48), http://forumoswiatowe.pl/index.php/Czasopismo/article/view/31 [dostęp: 12.03.2016].

Trześniewska A. (2010), Jak wygląda edukacja w Afryce?, http://www.edulandia.pl/edukacja/ 1,101856,7593250,jak_wyglada_edukacja_w_afryce.html [dostęp: 12.03.2016].

World Bank (2009), Namibia: Country Brief, The International Bank for Reconstruction and Development, Washington.

World Health Organization (2009), Blindness, poverty and development, The impact of Vision 2020 on the U.N. Millenium Development Goals.

http://dzieciafryki.com [dostęp: 12.03.2016].

http://www.dzieciafryki.org [dostęp: 12.03.2016].

http://kulczykfoundation.org.pl/eged [dostęp: 12.03.2016].

http://afryka.org [dostęp: 12.03.2016].

http://okuliscidlaafryki.pl/2014/03/01/edukacja-i-sytuacja-kobiet-w-namibii/ [dostęp: 12.03.2016]. http://www.znp.edu.pl/element/2132/Budzet_na_rok_2015_w_Sejmie [dostęp: 30.07.2016]. 